\title{
The use of Animals in Assisted Therapy: Systematic Review of the Literature
}

\author{
Silvia Maria Ribeiro Oyama ${ }^{1}$, Bruno Vilas Boas Dias*2, Gabriela Wanderlei ${ }^{3}$ and Marilia Gabriela da \\ Silva $^{3}$
}

${ }^{1}$ Doctor in Health Sciences, Pedagogical Coordinator of the Nursing course of the University Center Campo Limpo Paulista and Paulínia, Brazil

${ }^{2}$ Master in Health Sciences, Professor of Padre Anchieta University in Jundiaí and Campo Limpo Paulista University, Brazil

${ }^{3}$ Academics Nursing at University Center Campo Limpo Paulista, Brazil

Received: June 19, 2018; Published: June 25, 2018

*Corresponding author: Bruno Vilas Boas Dias, Center of Jundiaí SP, Padre Anchieta University, Brazil and Campo Limpo Paulista University Center, Campo Limpo, Brazil

\begin{abstract}
Animal assisted therapy refers to the use of animals such as dogs, cats, rabbits, turtles, birds, among others in the care of hospitalized patients. This study aimed to analyze the benefits of Dog Therapy for children with cancer. It is a systematic review of the literature, carried out in Scielo and with the descriptors "assisted therapy" and "animals" and in the VHL, with the descriptors "assisted therapy", "animals" and "pediatrics". The articles published in Portuguese and English, available in full, published between 2005 and 2017 were considered. We found 8 articles that dealt with the subjects: animal use in assisted therapy, hospital infection, role of the team in assisted therapy, humanization, lack of familiarity, recommendations and benefits of assisted therapy. It was observed that the Assisted Therapy brings innumerable benefits enabling improvement in the care for both the patient and the health professionals.
\end{abstract}

Keywords: Assisted Therapy; Animals and Pediatrics

\section{Introduction}

Childhood cancer is a generic term that refers to "a heterogeneous group of diseases that have morbidity and mortality rates that depend on the type and extent of disease, the age of the child and the effectiveness of the initial treatment response" [1,2]. Cancer reaches 10 out of every 1,000,000 children each year worldwide, with one child in 600 developing it during childhood, but it is now known that two-thirds of these cancers are considered curable if the diagnosis is early and the treatment administered is adequate for the type of cancer [2,3]. The incidence rate of childhood cancer has grown at around 1\% per year. In Brazil, cancer is already the third leading cause of death from 1 to 14 years, and in the city and state of São Paulo, it is the first cause of death between 5 and 14 years of age, excluding external causes [4]. Although cancer in children is considered rare in relation to adults, it is currently classified as the leading cause of death due to illness in children up to five years old, according to only deaths from violence and accidents [5]. With the cancer treatment, the child and the family suffer from the long periods of frequent hospitalizations and read missions. Having a child with cancer affects the entire family, and there is a chance of breaking these family ties, but if the family can adapt to this new routine and illness, their roles and responsibilities may change [6].
Due to the treatment the child is submitted to various hospitalizations and often for long periods of hospitalization, it is essential that the environment is as pleasant as possible for it. It is important that family, friends and people close to the child do not fail to visit him. In addition to taking the favorite toys and other objects that make the child feel the "taste" of home. The process of play is very important for the child at this stage of life as it helps in the development of physical, emotional, cognitive and social aspects. In children with cancer, play is an important tool to address the disease and treatment positively [7]. Hospitalization causes the child to become estranged from both the home and school environment, resulting in negative repercussions on academic achievement and socialization. In many cases, parents even quit their jobs, change their city, and make difficult decisions to accompany their child in the treatment of the Disease [8]. Animal-ssisted therapy (TAA) refers to services developed by health professionals, whose main element is the use of animals such as dogs, cats, rabbits, turtles, birds, among others in the care of hospitalized patients [9]. Among the animals most frequently used by nurses, the dog is distinguished by means of Assisted Dog Therapy (CAT), which has a natural affection for the people, is easily trained and creates positive responses to touch [10]. 
The earliest records of TAA use occurred around 1972, in England, by William Tuke, employed in the treatment of the mentally ill. In Brazil, he appeared with the psychiatrist Nise da Silveira in 1946, when he founded the Occupational Therapy Service in Rio de Janeiro, using cats as co-therapists for patients with mental disorders [11]. There are several benefits to the use of CT, both psychological and physiological: pain reduction, anxiety, reduction of heart rate, blood pressure, cholesterol levels and stress and the improvement in the interpersonal relationship of the child. With the presence of the animal the child ends up creating a bond with him and in this way feels more secure in expressing his feelings [10]. Nurses recognize their role as key in providing and ensuring that actions such as TAA allow the child and adolescent a chance to experience the love, affection and complicity that the animal can provide.

The experience of some nurses points out that the dog therapist, used in the chemotherapy unit and doctors' offices, has the role of assisting children and adolescents, giving them, their family and health team, the opportunity for inclusion in a care shared. According to nurses, TAA positively impacts the environment and, unlike what some people may think, the presence of the animal does not interfere with the routine of the unit. It is possible to notice a change in the physical state and reducing the chorus in response to the unknown [9]. Nurses consistently seek interventions that reduce the stress of hospital admission and facilitate the treatment of cancer. For this reason, the use of alternative therapies in care that are capable of developing strategies to make it less traumatic have been valued10.Assisted animal therapy is an important strat- egy forthe humanization of hospitalized child care [12]. This study aims to analyze the benefits of dog therapy for children with cancer.

\section{Method}

This is a systematic review of the literature. The systematic review is one of the forms of research that uses the available literature on a given topic as a data source. The review provides a summary of the evidence related to a specific intervention strategy, through the use of explicit and systematized methods of searching, critical appraisal and synthesis of selected information. They are used as a way of integrating information from a set of studies performed separately on a particular therapy or intervention, which may present conflicting and / or coincident results, as well as identify subjects that need evidence, assisting in guiding future investigations [13]. The research was carried out in Scielo, with the descriptors "assisted therapy" and "animals". In the VHL, the descriptors "assisted therapy","animals" and "pediatrics" were used. Articles published in Portuguese and English, available in full, published between 2005 and 2017 were considered. Also used was the law that addresses the subject. LAW № 16.827, OF FEBRUARY 6, 2018.

\section{Results}

Based on the inclusion criteria established in this bibliographic review, 8 articles were selected (Figure 1).

The selected articles were also analyzed according to the journal and year of publication, type of study, objective and main findings, as presented in Table 1.

Table 1: Distribution of articles according to journal and year of publication, type of study, objective and main findings, as presented. Brazil, 2018.

\begin{tabular}{|c|c|c|c|c|c|}
\hline & Journal & Year & Type of study & Objective & Main findings \\
\hline 1 & $\begin{array}{l}\text { Brazilian Journal of } \\
\text { Nursing }\end{array}$ & 2016 & Qualitative & $\begin{array}{l}\text { To learn the perception of professionals } \\
\text { of the nursing team and responsible for } \\
\text { children and adolescents with cancer about } \\
\text { the Assisted Therapy with Dogs. }\end{array}$ & $\begin{array}{l}\text { The participants' perceptions reinforce the } \\
\text { recommendations applicable in the hospital } \\
\text { context and show that the practice in question } \\
\text { can become an effective technique for health } \\
\text { promotion in children and adolescents with } \\
\text { cancer. }\end{array}$ \\
\hline 2 & $\begin{array}{l}\text { Nursing School } \\
\text { Magazine }\end{array}$ & 2005 & Case study & $\begin{array}{l}\text { To know the perception of an adolescent } \\
\text { with recurrent acute lymphocytic } \\
\text { leukemia, about the visit of her pet dog } \\
\text { during hospitalization, in how the nursing } \\
\text { interventions. }\end{array}$ & $\begin{array}{l}\text { Because of its evolution, TAA has shown an } \\
\text { important therapeutic potential in terms of } \\
\text { psychological aspects. Therefore, its use should } \\
\text { be extended to other clinical situations that } \\
\text { contribute to the understanding and application } \\
\text { of this intervention by nursing. }\end{array}$ \\
\hline 3 & $\begin{array}{l}\text { Brazilian Journal of } \\
\text { Nursing }\end{array}$ & 2009 & Case study & $\begin{array}{l}\text { Providing patients with a positive experience } \\
\text { that differs from the routine of the hospital } \\
\text { environment, some units of the São Paulo } \\
\text { Hospital were visited by an animal for } \\
\text { sessions of Animal-Assisted Therapy. }\end{array}$ & $\begin{array}{l}\text { The results achieved among patients, caregivers } \\
\text { and health professionals were positive, as well } \\
\text { as attracting attention and interest from other } \\
\text { health institutions and the media }\end{array}$ \\
\hline 4 & $\begin{array}{l}\text { Magazine Of The } \\
\text { Medical Association } \\
\text { Of Rio Grande Do Sul }\end{array}$ & 2015 & Quantitative & $\begin{array}{l}\text { To identify the socio-demographic profile of } \\
\text { patients, caregivers and health professionals } \\
\text { involved in the pediatric area of a university } \\
\text { hospital and their opinion on Animal- } \\
\text { Assisted Activity }\end{array}$ & $\begin{array}{l}\text { The research carried out showed an openness } \\
\text { of the interviewees for AAA implementation. } \\
\text { And it may, perhaps, serve as a stimulus for our } \\
\text { health professionals to analyze, from another } \\
\text { perspective, this innovative and internationally } \\
\text { accepted activity. }\end{array}$ \\
\hline
\end{tabular}




\begin{tabular}{|c|c|c|c|c|c|}
\hline 5 & $\begin{array}{l}\text { Latin American } \\
\text { Journal of Bioethics }\end{array}$ & 2014 & $\begin{array}{l}\text { Systematic } \\
\text { review }\end{array}$ & $\begin{array}{l}\text { It aimed at the improvement and well-being } \\
\text { of the patient. Its efficacy has been proven } \\
\text { through studies worldwide, in different } \\
\text { areas such as pediatrics, geriatrics and } \\
\text { psychiatry, among others, and bringing } \\
\text { both physical and mental health benefits of } \\
\text { institutionalized people }\end{array}$ & $\begin{array}{l}\text { Animal activities may combine with traditional } \\
\text { therapy aimed at the well-being of the } \\
\text { hospitalized patient and the extent of their } \\
\text { recovery or excellent palliative minimizing } \\
\text { stress, anxiety and other clinical factors for their } \\
\text { treatment. }\end{array}$ \\
\hline 6 & $\begin{array}{l}\text { Archive Brazilian } \\
\text { Veterinary Medicine } \\
\text { and Zootechnics }\end{array}$ & 2012 & Quantitative & $\begin{array}{l}\text { To analyze the effects of assisted therapy } \\
\text { in the dogs therapists in the hypothesis } \\
\text { that such activity can trigger stress, using } \\
\text { as means the measurement of serum } \\
\text { and salivary cortisol values, parametric } \\
\text { variations and observation of behavioral } \\
\text { changes }\end{array}$ & $\begin{array}{l}\text { Animal-assisted therapy does not appear to } \\
\text { cause significant stress to dogs, and does not } \\
\text { directly interfere with well-being and health, } \\
\text { since changes in physiological parameters and } \\
\text { salivary cortisol concentrations appear to be } \\
\text { related to the containment and manipulation } \\
\text { of the animal to obtain the samples, and also } \\
\text { because no negative stress behavior was } \\
\text { observed. In this way, TAA should be emphasized, } \\
\text { since it provokes benefits to humans and does } \\
\text { not harm the animal. }\end{array}$ \\
\hline 7 & DOR Magazine & 2016 & $\begin{array}{l}\text { Quantitative / } \\
\text { qualitative }\end{array}$ & $\begin{array}{c}\text { To evaluate the effectiveness of the activity, } \\
\text { education and therapy assisted by animals, } \\
\text { based on international bibliographical } \\
\text { references. }\end{array}$ & $\begin{array}{l}\text { There was a significant decrease in pain } \\
\text { sensation after the intervention with dogs, } \\
\text { confirming some international studies on the } \\
\text { subject, showing the importance of future } \\
\text { studies in the area, which are still scarce in } \\
\text { Brazil. }\end{array}$ \\
\hline 8 & Nursing Focus & 2017 & $\begin{array}{l}\text { Descriptive, } \\
\text { exploratory, } \\
\text { transversal } \\
\text { character }\end{array}$ & $\begin{array}{l}\text { To verify the playful interaction between } \\
\text { children and dogs in the activity assisted by } \\
\text { animals. }\end{array}$ & $\begin{array}{l}\text { They suggest a perspective with great potential } \\
\text { to be explored and implemented in pediatric } \\
\text { units, of low cost, with minimum risk since the } \\
\text { adopted safety recommendations mentioned in } \\
\text { the protocol. }\end{array}$ \\
\hline
\end{tabular}

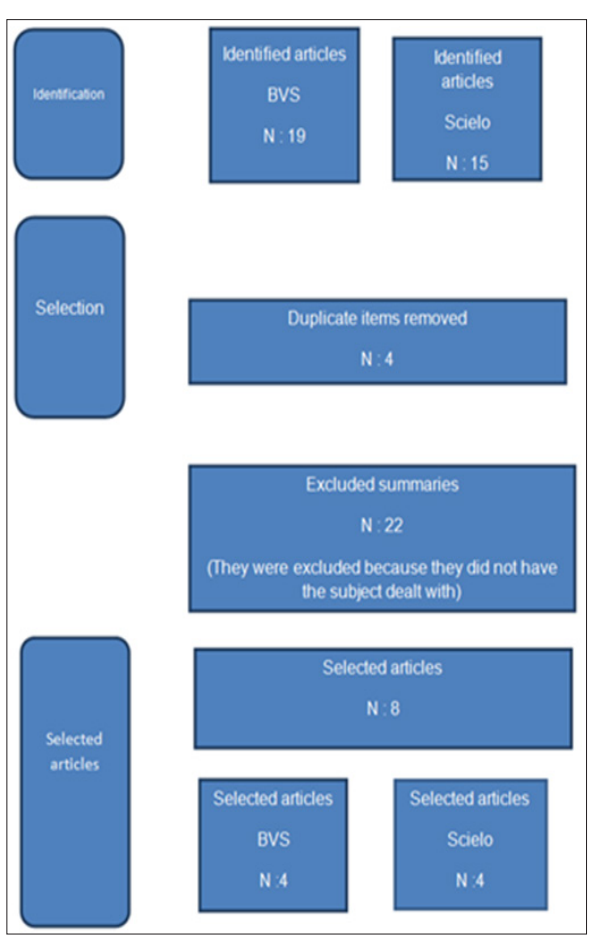

Figure 1.

\section{Discussion}

The subjects of the eight selected articles can be separated into 7 thematic ones: animal use in assisted therapy, hospital infection, team role, humanization, unfamiliarity of family members, recommendations and benefits as shown in the chart below (Figure 2).

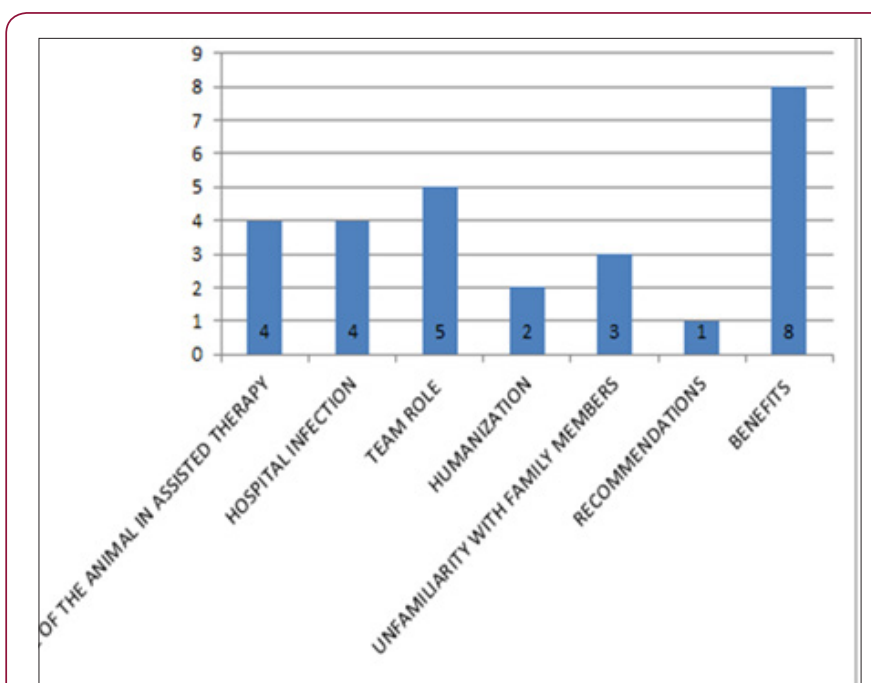

Figure 2.

\section{Use of the Animal in Assisted Therapy}

The dog is the animal most used for this type of therapy, having a natural bond with humans and being a docile animal, calm and easy to train. It is well accepted to be touched, caressed, and well-regarded by people [14]. Remembering that the dog is not the only animal that can be used in this type of therapy, other animals are also used, such as birds, cats, guinea pigs, dolphins and horses. The selection of the animal is a very important aspect for the therapy, since it must be friendly, docile, affectionate and accustomed to TAA sessions in a hospital environment. The behavior of the animal needs to be evaluated, to be able to remain calm in an unknown en- 
vironment with unknown people, to see his reaction with different noises, with an aggressive voice or threatening gestures, reaction to strong hugs and interaction with other animals [16]. The animal must have attestation of health, be with its vaccines in day [14-16]. All dogs go through a type of selective process before they become volunteers. They need to be able to practice this activity.

They identify the profile of the dog and verify if it is appropriate for the practice, in addition to the behavior, it is imperative that the animal on the day that the visits are showered and have adequate transportation [17]. The visit of the dog has become a routine in the selected units, they have pre-selected days and times and a certain time for the stay in the place. They are accompanied by their owner and volunteer, by social workers, doctors and nursing staff. On visits, dogs are taught not to accept food or drinks, not to do their needs on the spot and must obey the commands of their owner, who can help with requests from patients and relatives [14]. A research was carried out in the city of Araçatuba, published in the year 2012, in order to verify if the animal suffers some damage with the use of the therapy. It was evaluated the behavior and the physiological effect that can cause in the animal, being in a new environment with unknown people.

They made an evaluation at various moments of the animal, at home, during the sessions and soon after the therapy. To check if it causes any type of stress in the dog. It has been proven by tests such as samples of saliva, respiratory rate, blood pressure and temperature that does not cause any stress to the animal. The behavioral evaluation also did not have negative effects, since they do not feel frightened and do not present aggressive behavior [18]. Assisted therapy does not cause any harm to the animal.

\section{Hospital Infection}

One of the greatest problems experienced within the hospital environment is the risk of hospital infection. Currently all hospitals adopt precautionary measures to avoid this problem. When it comes to animal assisted therapy it is no different. The greatest fear on the part of the multiprofessional and even patient and family team is the risk of infection. However, it is known that for animals to enter hospitalization units they undergo a rigorous evaluation criterion in order to know if they are / are able to participate in assisted therapy [15]. Studies carried out in the city of São Paulo, published in 2009 regarding hospital infection, show that the rate in animals passing infection to patients is lower in relation to a visitor transmitting. This, when the animals follow all the questions to carry out the visit [14]. Other studies also show that after years of animal assisted therapy, the number of infections did not change during the visitation period. For the visits to be performed, it is necessary to follow several questions, besides authorization of the hospital infection commission. It is also extremely important to strengthen patients and family members to clean their hands after handling the animal.

In a study carried out in the city of São Paulo, in 2003 it was observed that some entities that work with the control of hospital infection indicate that the animals can be sources of infection.
However, if the guidelines are carefully followed for the therapy, the risk is minimal [7]. Another major concern of the multi professional team and family-related therapy would be with patient's immune suppressed due to possible opportunistic infections. However, studies show that the number of infections in units with immune suppressed patients who receive the visit and units that do not receive the same rate. Always remembering that all animals must be fit in some aspects in order to be able to visit patients [10].

\section{Role of the Team}

Role of the Assisted Therapy has been performed and known for some time, it was once used in patients with psychological problems, but unfortunately is still little used by the nursing and general health team, as they do not have sufficient knowledge of the therapy and of its benefits. Few nursing professionals know the importance of assisted therapy on the patient, there are studies demonstrating the effectiveness and benefits that the use of therapy can cause in the patient. Nursing professionals claim that they do not have enough knowledge to use this technique and that if there was a protocol that would help in dealing with this situation it would be more practical [10], explaining what benefits they can cause in the patient, in what way staff can help when the dog visits the hospital, which animals can be used in assisted therapy. Basic information that could make a difference for the professionals who are there everyday with the patient, since they are not accustomed to the visit of the dog in their day to day life, but to the daily activities of the sector [11]. This same old technique is starting to get more visibility in hospitals today.

A study conducted at a referral hospital in the north and northeast from October 2014 to February 2015 in patients diagnosed with childhood and juvenile cancer with some nursing professionals has proven that assisted therapy helps in patient interaction with the nursing team, since the professionals noticed the difference and the collaboration of the patients after they implemented the therapy in the hospital [10]. They realized that the use of the animals improves the communication and the trust between the professional and the patient. Hospitalized children and adolescents end up collaborating with staff on procedures, they feel more confident and relaxed in the hospital environment, knowing that that place can also provide a pleasant and relaxed environment. Sometimes forgetting that they are in a hospital. He observed that CT helps to cope with the treatment of the disease, allowing an adaptation to the hospital environment and helping to reduce the stress, anxiety and trauma of hospitalization [10]. The visit of the dog leaves the patient more relaxed and facilitates much the role of the nursing team, as there are some patients who are shy or who are very frightened by the hospitalization and end up not being able to communicate with the team.

With the visit of the dog this communication becomes easier, the patients become more communicative and the professionals can draw subject on the dog itself with the patient, thus improving the communication and interaction between them. The use of assisted therapy ends up being a relaxing time for both the patient and the nursing team, because it is different if you communicate with 
the patient in an enclosed room that is only you, the patient and the companion at most, or a environment appropriate to receive the visit of the dog who are all relaxed and enjoying the moment of relaxation. There the nurse can provide a different environment than the patient is accustomed and can increase mobility and even muscle activity, encouraging the patient to caress and comb the animal. Outside Brazil there are specific courses that are focused on nurses who want to follow this area of assisted therapy, enjoying their physical, cognitive, emotional, physiological and behavioral benefits [10].

\section{Humanization}

Assisted therapy is a humanized form and a different experience for the patient who is accustomed to the routines of a hospital environment, providing joy and relaxation to patients. With the visits of the animals they feel somehow closer to the familiar environment. The multiprofessional team is extremely important with regard to the process that the patient undergoes during his hospitalization. It is necessary to evaluate the patient as a whole, aiming to develop a therapeutic plan in an individualized way. For 7 years, the National Health Care Program (PNHAH) was developed by the Ministry of Health, whose objective is always aimed at improving care in respect to life. In this way, the team has full responsibility and duty to develop the best interventions for patients. This statement refers to the good practices that must be performed, considering the patient's point of view, in order to improve care [14]. Some institutions observe in Therapy one of the best innovations and interventions in relation to Humanization. Thus, the health team becomes the main responsible for proposing interventions for the patients, thus, making the hospitalization less traumatic, obtaining positive results and improving the patient experience [19].

\section{Unawareness of Family Members}

One of the fears of family members with the visit of the dog to the oncologic patient is the state of immune suppression that facilitates the appearance of opportunistic infections. They believe that with the visit of the dog the same can help to transmit possible infections that can aggravate the situation of the patient [10]. But when explaining the entire process to the patient's relative or companion, the patient feels confident and happy to see the happiness the dog's visit gives the patient. TAA needs to be more recognized because it is a great process for patients, parents and health professionals.

\section{Recommendations}

Some recommendations are important for the use of assisted therapy, both for the patient, the health team and the animal used. For the patient it is essential the authorization of the same or the responsible in case of minors, to verify if it does not have phobia by animals. It is not recommended for patients who have allergies or breathing problems. Not being able to mistreat the animal, avoiding the animal lick the skin, wounds or devices. Avoid contact with saliva, urine and animal feces. And always communicate if there is any kind of incident involving the animal. For the animal it is important to be clean and with the vaccines on time, be trained for this type of therapy and have approval and authorization from the hospital infection committee. The implementation of the TAA should follow some rules to maximize the benefit of the practice and minimize the risks. The health team and program coordination must agree to the implementation of the TAA in the hospital unit. The use of TTA in intensive care units should be restricted; restricted units such as surgery rooms, sterilization center, isolation, drug preparation room, as well as spaces such as laundry or kitchen [13].

\section{Benefits}

When we deal with an illness situation in the family, this becomes a suffering for everyone, especially when it comes to a child. As much as the family has a great foundation it ends up that everyone gets sick or feels powerless with the situation. The family is forced to change their whole routine to fit this new situation. These are days and more days of hospitalization, often far from the city where you live. With that, it ends up changing the whole life of this child, being unable to go to school anymore, playing in the street, the conviviality with family and friends ends up diminishing because of the treatment and the very privacy of the child and the adolescent. With this they become more sad and even depressive. Affecting both the child and parents or guardians [6-7]. Analyzing the studies carried out, we verified that the use of CT is a great benefit to hospitalized patients and family members who closely follow the treatment, because it brings joy, comfort and more social interaction.

There are several benefits that can be seen in patients participating in assisted therapy, such as decreased anxiety, fear, sadness, anguish, isolation and even homesickness, as they end up making a connection between the home environment and the visit of the animal, feel closer to home [10]. One of the main and most relevant benefits with the use of assisted therapy is the reduction of pain to the patient [15-19] due to stimulation of endorphin production, increase of oxytocin, prolactin and dopamine, which are the hormones better known as "hormones happiness, "which give the feeling of well-being, comfort, better state of humor and joy [16]. In relation to the hormonal factors we can verify the decrease of the anxiety on the part of the patients due to the decrease of the plasma concentration of cortisol, substance that acts directly in the state of anxiety [10]. According to studies conducted in Brazil and in the city of São Paulo, in the years 2014 and 2014/2015 related to the use of assisted therapy, they can prove that patients who underwent this type of therapy had a positive response, related to vital signs, such as a decrease in blood pressure, respiratory rate, and body temperature [15-16].

They also had a reduction in cholesterol levels [14]. It was noticed that there was an improvement in the adherence to the treatment by the patients after the insertion of the therapy in the hospitals, due to the defocalization of the hospitalization. With the increase of the interaction of the patients in the activities proposed in groups, facilitating and contributing in the communication between the patients themselves and with the professional staff [1014]. Considering the good relationship and good development in the proposed activities, it is possible to observe the change in the 
perception of the hospital environment by patients and their families [14-17]. With hospitalization and situational change, patients become more stressed, causing them to end up affecting their emotions a lot.

With the visit of the animal they feel at ease in a more relaxed environment, because they forget at that moment by all the difficulties that pass or have passed and they manage to be happy with the presence of the animal, which stimulates the children to maintain physical contact. Positive emotions only increase and negative emotions decrease. We have a significant decrease of stress, a recovery of self-esteem and sensitivity [14-20]. In a study carried out in the city of Porto Alegre, published in the year 2015, the companions, patients and health professionals were interviewed to see if they are in favor of this practice. The majority of respondents are favorable to TAA because they are accustomed to animals, and because they have pets [19]. In a study with patients and relatives, it was verified that most of them are favorable to TAA, and report the need to have an appropriate place to receive the animal, such as a recreation room. They also reported knowledge related to the training of the animal, but they did not know how to detail the information about this training. They also denied knowledge related to medical evaluation in order to practice therapy [19].

\section{Law}

There is a law that deals with the subject. The law is No. 16,827, February 6, 2018. This document addresses the release of pets into public hospitals for inpatient visits, in which pets are allowed in public hospitals for visits to patients internships; emphasizes that the pets to visit must be vaccinated on time and sanitized, and the responsible person must prove, by means of a veterinary report, the good health condition of the animal. The entry of the animal will depend on authorization from the hospital's infectious disease committee. It will be up to the hospital to create norms and procedures to organize the time and the place of stay of the animals for visitation of hospitalized patients [21].

\section{Final Considerations}

It was possible to verify that the Assisted Therapy brings innumerable benefits enabling improvement in the care for both the patient and the health professionals. However, it is still of low knowledge by the multi professional team and institutions, where it would be possible to implement the technique. Because there are currently no significant amount of studies on the subject in Brazil. However, abroad the technique is better known and used.

\section{References}

1. Ribeiro EMPC (1994) 0 paciente terminal e a família. Introducao a psiconcologia Sao Paulo 2: 210-214.
2. Menezes CNB, Passareli PM, Drude FS, Santos MA ,Valle ERM, et al. (2007) Cancer infantil: organizacao familiar e doenca. Rev. Mal-Estar Subj 7(1): 191-210.

3. Valle ERM, Francoso LPC (1999) Psicooncologia pediatrica: Vivencias de criancas com cancer. Ribeirao Preto. SP: Scala.

4. Rodrigues KE (2003) Camargo Diagnóstico precoce do câncer infantil: Responsabilidade de todos.Rev assosc Med Bras 49(1): 29-34.

5. Silva LF, Cabral IE (2014) As Repercussões do câncer no brincar em crianças: implicações para o cuidado de enfermagem. Texto Contexto Enferm 23(4): 935-943.

6. Nascimento LC, Rocha SMM, Hayes VH, Lima AG (2005) Crianças com câncer e suas famílias. Rev Esc Enferm 39(4): 469-474.

7. Silva LF, Cabral IV (2015) O resgate do prazer de brincar da criança com câncer no espaço hospitalar. Rev Bras Enferm 68(3): 391-397.

8. Benedetti GMS, Garanhani ML (2014) Sales CA Rev Latino-Am. Enfermagem 22(3): 425-443.

9. Almeida FA, Nascimento AA, Duarte AM (2016) Terapia Assistida por Animais: A Experiência dos Enfermeiros com o Uso Desta Prática em um Hospital Oncológico. Investigação Qualitativa em Saúde 738-747.

10. Moreira RL, Gubert FA, Sabino LMM, Benevides JL, Tomé MABG, et al. (2016) Terapia Assistida com cães em Pediatria Oncológica: Percepção de pais e enfermeiros. Rev Bras Enferm 69(6): 1188-1194.

11. Juliano RS, Fioravanti MCS (2009). Terapia assistida por animais (TAA): revisão para profissionais da saúde Adolescentes: uma abordagem multidisciplinar. São Paulo: Martinari 421-436.

12. Vaccari AMH, Almeida FA (2007) A importância da visita de animais de estimação na recuperação de crianças hospitalizadas. Einstein 5(2): 111-116.

13. Sampaio RF, Mancini MC (2007) Estudos de revisão sistemática: Um guia para síntese criteriosa da evidencia cientifica. Rev fisioter 11(1): 83-89.

14. Kobayashi CT, Ushiyama ST, Fakih FT, Robles RAM, Carneiro IA, et al. (2009) Desenvolvimento e implantação de Terapia Assistida por Animais em hospital universitário. Rev Bras Enferm 62(4): 632-636.

15. Crippa A, Feijó AGS (2014) Atividade assistida por animais como alternativa complementar ao tratamento de pacientes: a busca por evidências científicas. Rev Latinoam Bioet 14(1): 14-25.

16. Ichitani T, Cunha MC (2016) Atividade assistida por animais e sensação de dor em crianças e adolescentes hospitalizados. Rev Dor 17(4): 270273.

17. Bussotti EA, Leão ER, Chimentão DMV, Silva CPR (2005) Assistência individualizada: posso trazer meu cachorro?. Rev Esc Enferm 39(2): 195-201.

18. Yamamoto KCM, Silva EYT, Costa KN, Souza MS, Silva MLM, et al. (2012) Avaliação fisiológica e comportamental de cães utilizados em terapia assistida por animais (TAA). Arq Bras Med Vet Zootec 64(3): 568-576.

19. Crippa A, Costa GC, Feijó AGS (2015) Atividade Assistida por Animais na Pediatria. Revista da AMRIGS 59(3): 243-247.

20. Pereira VR, Nobre MDO, Capella S, Vieira ACG (2017) Interação lúdica na atividade assistida por cães em pediatria. Enferm Foco 8(1): 7-11.

21. Lei N (2018) Prefeitura do Município de São Paulo. De 6 de fevereiro de. 
(c) (P) This work is licensed under Creative Submission Link: https://biomedres.us/submit-manuscript.php

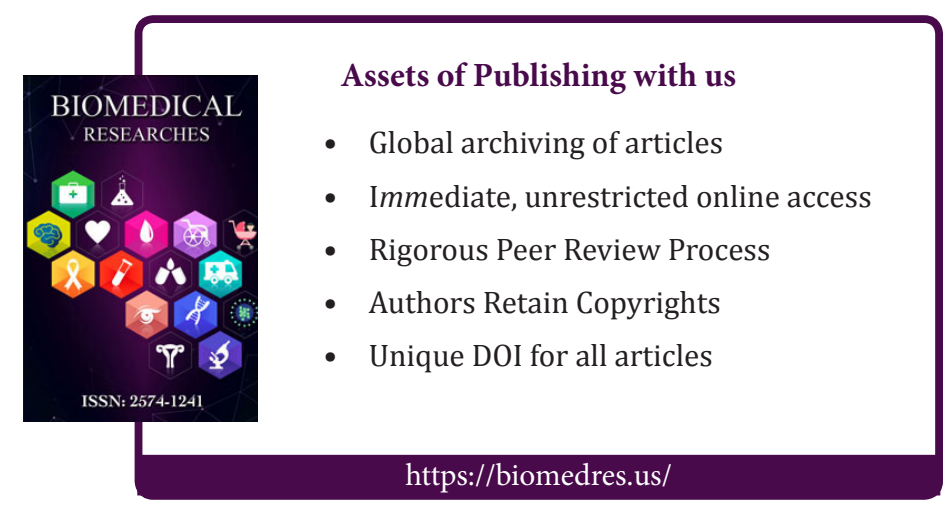

